\title{
Reviews of Tax Planning
}

\author{
Manxia Yuan, Xi Xu \\ School of Management, Jinan University, Guangzhou, China \\ Email: jdymx2009@126.com
}

Received 23 October 2015; accepted 13 November 2015; published 16 November 2015

Copyright (C) 2015 by authors and Scientific Research Publishing Inc.

This work is licensed under the Creative Commons Attribution International License (CC BY).

http://creativecommons.org/licenses/by/4.0/

c) (i) Open Access

\begin{abstract}
This article reviewed the researches on tax planning published in the domestic and foreign authoritative magazines, and found that scholars put their emphasis on three points: research on the motivation of tax planning; research on the measurement of tax planning; research on the economic consequences of tax planning. With the improvement of the market economy system and the tax system in our country, tax planning can help enterprises to achieve maximum direct economic benefits and value. Besides, with the four-year reform of "business tax to value-added tax" coming to the end, it is particularly important for the enterprises to establish effective corporate tax planning strategy to achieve the scientific and sustainable development.
\end{abstract}

\section{Keywords}

Motivation of Tax Planning, Measurement of Tax Planning, Economic Consequences of Tax Planning

\section{Introduction}

In 2012, the APPLE Company paid \$14 billion taxes for the $\$ 55.76$ billion annual pre-tax income, and after comprehensive calculating, we found that the total tax rate is only $22 \%$, far lower than the federal rate. As the world's most profitable enterprise, its tax planning also did a best job.

Tax planning in developed countries is very common and has become a mature industry, and its specialization trend is clear. More than $60 \%$ of the companies in the United States appoint a tax agent to handle their tax work, and the rate in Japan is as high as $85 \%$. The annual output of tax consult industry is about $\$ 100$ billion in the United States. By contrast, the development of tax planning in China is still at the starting stage. It is not until the establishment of the market economy system that the tax becomes an important factor for corporate interests. On January 1, 2000, the Chinese Tax Newspaper, supervised by the State Administration of Taxation, set up "tax planning" column to introduce the basic principle and method of tax planning for taxpayers, which shows that Chinese government departments began to face up to tax planning issues. 
Tax planning, an important throttling way for enterprises by making a complete tax operation scheme through the planning of tax-related business, has caused more and more attention in business world and academic world.

The following content is divided into two parts. The first part is the reviews of Tax Planning, including reviews on the motivation of tax planning, reviews on the measurement of tax planning and reviews on the economic consequences of tax planning. The last part is the conclusion, illustrating the existed opinions on Tax Planning and trying to find new understandings of tax planning.

\section{Reviews of Tax Planning}

\subsection{Reviews on the Motivation of Tax Planning}

Cloyd et al. [1] held an investigation about the large and medium-sized public and private manufacturing enterprises with the method of questionnaire survey, and the survey found that enterprise managers' behavior motive and their behavior would affect the degree of enterprise tax planning, and pointed out that the personal cost of public enterprise executives for tax planning was higher, which lead to the desire of tax planning for the public enterprises is not strong.

Mills and Newberry [2] took the manufacturing enterprises in the United States as the research object, analyzed the difference of tax planning degree between the private listed companies and the public listed companies, and believed that the cost of financial report for the listed enterprise managers is a major determinant of whether the listed companies would conduct tax planning or not, the cost of financial report for public listed enterprise managers is higher, thus the motivation for tax planning is weaker.

Graham [3] took a questionnaire survey of the tax directors for 600 companies, and the study found that $69 \%$ of the tax directors would regard the costs of reputation as the main cause why they did not take tax planning strategy. Besides, they also found that financial accounting motivation is one of the important factors when considering tax planning strategy.

Domestic research took the property rights as the breakthrough point, and put much emphasis on the different tax planning policies caused by the different enterprise characteristics.

Ying Du, Liguo Liu [4] analyzed the different choice in tax planning strategy between the executives of stateowned enterprises and non-state-owned enterprises, and the results showed that relative to the non-state-owned enterprises, tax planning motivation for state-owned enterprises is smaller, the reason for this is that state-owned enterprises executives had pressure in performance appraisal and political promotion, and tax contribution is set to be an important indicator of performance for the state-owned enterprises executives.

Ying Lin [5] divided the 31 provinces and cities in our country into four major economic zones by the region partition method, she collected and counted up the tax data of every economic zone from 1994 to 2006, and found significant regional tax gap of our country, she also pointed out that the difference of corporate ownership structure between the zones was the fundamental reasons of this phenomenon, such as the area where the state-owned enterprises accounted for a larger part, the tax revenues were high, which reflected from the side that our state-owned enterprises pay more taxes, i.e. the degree of tax planning in state-owned enterprises was weak.

Wei Lv [6] took the implementation of the new Enterprise Income Tax Law as an opportunity and researched the relationship among trace-analysts, property rights arrangement and the company's tax avoidance behavior; he found that with more trace-analysts, lower degree of information asymmetry, the enterprises' implicit tax cost was lower, which would lead to a more aggressive tax avoidance behavior.

\subsection{Reviews on the Measurement of Tax Planning}

1) The effective tax rate method

The most widely existing calculation method for tax planning is the effective tax rate method (ETR), because of the different purpose, definition of molecule and denominator in ETR metrology will have big difference. By reviewing and sorting, the following four methods have been widely used to calculate the effective tax rate:

a) ETR = Income tax expenses/Earnings Before Interest and Tax [7]

b) $\mathrm{ETR}=$ (Income tax expenses-deferred income tax expenses)/Earnings Before Interest and Tax [7]

c) ETR = Income tax expenses/profit before tax-deferred income tax expenses/statutory rates [8]

d) $\mathrm{ETR}=$ (Income tax expenses-deferred income tax expenses)/(profit before tax-the deferred tax changes/ 
statutory rates) [9]

A large number of domestic scholars adopt the effective tax rate index as the measurement of the tax planning for the listed company, i.e. ETR = The current income tax/the main business income.

2) Long-term effective tax rate method

Dyreng et al. [10] put forward the long-term effective tax rate method, i.e. the actual payable taxes in ten years divided by the pre-tax profits of the same period, and use the payable cash taxes as the molecules, which would avoid the influence of the volatility of each year for the effective tax rate method and avoid the mismatch problem for cash taxes and profits. Considering the tax rebates and the tax dispute between corporate and tax collection and administration department may last for several years, it is inappropriate to just use the current effective tax rate measuring corporate tax avoidance, and a more effective method is to take the average effective tax rate for many years to depict enterprise tax. Because of this, Hang Liu [11] using the five-year-average of "the difference between nominal income tax rates and the actual income tax rate" (from $t-4$ to $t$ ) to measure the business tax.

3) Difference between Accounting and Tax

Difference between Accounting and Tax can directly provide related information of tax planning behavior caused by the difference between Accounting and Tax.

Desai et al. [12] took a deep study on the growing phenomenon of the difference between Accounting and Tax, and found that the main reason of the growing difference between Accounting and Tax is the growing increase in tax planning behavior for enterprise.

Fuquan Zeng, Min Lv [13] had an empirical analysis about the relationship between the Accounting-Tax difference and the income tax avoidance with the preliminary evidence from Shanghai and Shenzhen A-share listed companies, and found that the greater the difference between Accounting and Tax was, the lower the income tax burden was, and the greater the income tax avoidance was. These studies have proved that the difference between Accounting and Tax can show some part of the tax planning, which proves that regard the difference between Accounting and Tax as a measurement for tax planning is rational.

\subsection{Reviews on the Economic Consequences of Tax Planning}

Comprehensive reviews on existing literature both at home and abroad, we found that the proposed tax planning behavior would produce a series of explicit and implicit results. Explicit results including the increase in cost that can be deducted, which further increases the cash flow and the wealth of the shareholders; indirectly, including the reduce in the earnings of the interest tax shields, which may change the enterprise's capital structure decision [3], so they think that tax planning is a kind of activity that can increase the enterprise value. And another implicit result is that the companies may be limited by the more attention and review of the taxation authority, forced to pay the additional taxes or interest and penalties, brought huge reputational damage, thus reducing the cash flow and the wealth of shareholders. Hanlon and Slemrod [14] analyzed the market reaction after the enterprises adopt specific tax avoidance policy, and found that share prices changed $-1.04 \%$ after the first announcement about the news of tax shields. Their further study in 2010 found that the bigger the scale of the company was, the more vulnerable its tax planning behavior was to the media, which would lead to the increase of political costs.

Dong Chen, Jianxin Tang [15] did a research on the relationship among executive pay, tax avoidance rentseeking and accounting information disclosure, and found that the increase of corporate tax avoidance results in deterioration in the quality of the accounting information disclosure.

Hang Liu, Kangtao Ye analyzed the correlation between the degree of enterprises tax avoidance and the efficiency of investment based on the data of Chinese listed companies from 1999 to 2010, and found a positive correlation, and the positive correlation relationship mainly reflected as tax avoidance caused the excessive investment; besides, they also pointed out that perfecting the corporate governance mechanism can restrain the influence of the tax avoidance on excessive investment.

\section{Conclusion}

In conclusion, the scholars studied the motivation of tax planning mainly from the respects of enterprise managers' behavior motive and property rights, and demonstrated the economic consequences of tax planning with explicit and implicit results. But there are still some problems in the research: taking the motivation of tax planning 
for example, foreign scholars mainly focused on the management behavior, and the domestic scholars mainly put emphasis on property rights, but few scholars tried to explain it from executives’ background characteristics or the personal traits of the executives. Executives are the key to the formulation and implementation of tax planning, and executive background characteristics directly reflect their cognitive abilities and values, which will affect the behavior of the executives and their decision making about the tax planning. Therefore, researches on executives' background characteristics and tax planning from the micro-perspective will deepen the understanding of tax planning and strengthen the construction of senior management team.

\section{References}

[1] Cloyd, C.B., Pratt, J. and Stock, T. (1996) The Use of Financial Accounting Choice to Support Aggressive Tax Positions: Public and Private Firms. Journal of Accounting Research, 34, 23-43. http://dx.doi.org/10.2307/2491330

[2] Mills, L.F. and Newberry, K.J. (2001) The Influence of Tax and Nontax Costs on Book-Tax Reporting Differences: Public and Private Firms. Journal of the American Taxation Association, 1, 1-19.

http://dx.doi.org/10.2308/jata.2001.23.1.1

[3] Graham, J.R. and Tucker, A.L. (2006) Tax Shelters and Corporate Debt Policy. Journal of Financial Economics, 3, 563-594. http://dx.doi.org/10.1016/j.jfineco.2005.09.002

[4] Du, Y. and Liu, L.G. (2002) Ownership Structure and Corporate Governance Efficiency: An Empirical Analysis of the Listed Companies in China. Management World, 11, 124-133.

[5] Lin, Y. (2009) An Empirical Analysis of the Tax Differences between Regions in China. Journal of Tax Research, 8, 54-58.

[6] Lv, W. (2010) Trace-Analysts, Property Right Arrangement and Enterprise Tax Avoidance-Empirical Evidence after the Introduction of the New Enterprise Income Tax Law. Journal of Shanxi University of Finance and Economics, 11, 60-66.

[7] Porcano, T. (1986) Corporate Tax Rates: Progressive, Proportional or Regressive. Journal of the American Taxation Association, 7, 17-31.

[8] Stickney, C.P. and McGee, V.E. (1982) Effective Corporate Tax Rates: The Effect of Size, Capital Intensity, Leverage and Other Factors. Journal of Accounting and Public Policy, 1, 125-152. http://dx.doi.org/10.1016/S0278-4254(82)80004-5

[9] Shevlin, T. and Porter, S. (1992) The Corporate Tax Comeback in 1987: Some Further Evidence. Journal of the American Taxation Association, 14, 58-79.

[10] Dyreng, S., Hanlon, M. and Maydew, E. (2010) The Effects of Executives on Corporate Tax Avoidance. The Accounting Review, 85, 1163-1189. http://dx.doi.org/10.2308/accr.2010.85.4.1163

[11] Liu, H. and Ye, K.T. (2013) Will Enterprise Tax Avoidance Activities Affect Investment Efficiency? Journal of Accounting Research, 6, 47-53.

[12] Desai, M. and Dharmapala, A.D. (2006) Corporate Tax Avoidance and High-Powered Incentives. Journal of Financial Economics, 79, 145-179. http://dx.doi.org/10.1016/j.jfineco.2005.02.002

[13] Zeng, F.Q. and Lv, M. (2010) Difference between Accounting and Tax, and Income Tax Avoidance: Preliminary Evidence from Shanghai and Shenzhen A-Share Listed Companies. Journal of Accounting Friends, 22, 71-74.

[14] Hanlon, M. and Slemrod, J. (2009) What Does Tax Aggressiveness Signal? Evidence from Stock Price Reactions to News about Tax Shelter Involvement. Journal of Public Economics, 93, 126-141. http://dx.doi.org/10.1016/j.jpubeco.2008.09.004

[15] Chen, D. and Tang, J.X. (2012) Executive Pay, Tax Avoidance Rent-Seeking and Accounting Information Disclosure. Journal of Economic Management, 5, 114-122. 